\title{
MOLECULAR STUDIES ON SOME VIRULENCE FACTORS OF PSEUDOMONAS AERUGINOSA ISOLATED FROM CHICKENS AS A BIOFILM FORMING BACTERIA
}

\author{
MARAM, M. TAWAKOL ${ }^{1}$; NEHAL, M. NABIL ${ }^{1}$ and REEM, M. REDA ${ }^{2}$ \\ ${ }^{1}$ Reference Laboratory for Veterinary Quality Control on Poultry Production-Dakahlia Branch- (Gamasa), Animal Health \\ Research Institute, Agricultural Research Center (ARC). \\ ${ }^{2}$ Reference Laboratory for Veterinary Quality Control on Poultry production-Dokki Lab.- Giza, Animal Health Research \\ Institute, Agricultural Research Center (ARC)
}

Received: 3 September 2018; Accepted: 30 September 2018

\begin{abstract}
This study was aimed to isolate and identify Pseudomonas aeruginosa (P. aeruginosa) from 150 diseased broiler chickens in addition to 50 environmental swabs from water pipes and tanks to examine their susceptibility against some commonly used antimicrobial agents, in addition to detection of some virulence genes using Polymerase Chain Reaction (PCR) and evaluation of its ability to form biofilm in vitro. Clinically the affected chickens were subjected to postmortem examination (P.M) then samples from internal organs such as (liver, heart, lung, spleen, and intestine); tracheal and environmental swabs were collected and subjected to bacteriological examination and identification. Twenty $P$. aeruginosa isolates were recovered from the diseased chickens and environmental swabs with an incidence of (10\%). Sixteen isolates were isolated from internal organs of 150 diseased chickens with an incidence of (10.66\%); meanwhile 4 isolates were recoded from 50 water pipes and tanks swabs with a percentage of $(8 \%)$. Antimicrobial sensitivity testing showed highly sensitivity to amikacin and colistin sulphate with percentages of (90\%) for each of them. Doxycycline showed resistance with a percentage of (75\%). PCR technique was a good tool for testing three virulence genes; $p s l \mathrm{~A}$, pelA and fliC genes; the three genes were detected in of the examined samples with a percentage of $(100 \%)$. A significant relationship between the existence of three virulence genes in the isolated P. aeruginosa and ability of biofilm formation (Slime producing ability) was reported in this study.
\end{abstract}

Key words: Pseudomonas aeruginosa, virulence genes, biofilm, chicken

\section{INTRODUCTION}

$P$. aeruginosa is a serious poultry pathogen and zoonotic bacterial agent causing nosocomial infections (Elsayed et al., 2016); it's associated with heavy economic losses in broiler farms (Devriese et al., 1975) causing significant morbidity and mortality (Hancock and Speert, 2000).

$P$. aeruginosa is a motile Gram negative rod shaped bacteria belonged to family Pseudomonadaceae (Blanc et al., 1998); grows readily on common bacteriologic media and producing a water-soluble green pigment composed of fluorescein and pyocyanin (Barnes, 2003). It's a ubiquitous organism usually associated with soil, drinking water, and humid environments (Mena and Gerba, 2009).

Corresponding author: Dr. MARAM, M. TAWAKOL

E-mail address: maram_salah82@hotmail.com

Present address: Reference Laboratory for Veterinary Quality

Control on Poultry Production-Dakahlia Branch- (Gamasa), Animal Health Research Institute, Agricultural Research Center (ARC).
Birds at any age may be infected; young birds are most susceptible. Severely stressed or immunodeficient birds and concurrent infections with viruses and other bacteria enhance susceptibility to Pseudomonas infection (Stipkovits et al., 1993). P. aeruginosa produce a variety of toxins and enzymes that may contribute to its pathogenicity (Lin et al., 1993), birds infected with $P$. aeruginosa suffer from septicemia, respiratory infections, sinusitis, keratoconjunctivitis and embryonic death rates in hatcheries (Hai-ping, 2009). It also produces cheesy deposits in serous surfaces lining air sacs and peritoneal cavity in addition to congestion of internal organs, perihepatitis and pericarditis (Riad, 1994).

Biofilms are intricate bacterial communities found attached to living or abiotic surface and surrounded by a bacterially produced extracellular matrix composed of exopolysaccharides, DNA and proteins (Whitchurch et al., 2002); Alginate, Psl and Pel are three exopolysaccharides that considered the main components in biofilm matrix (Al-Wrafy et al., 2016), these polysaccharides are produced by $P$. 
aeruginosa and determine its ability to form biofilm structure (Ghafoor et al., 2011).

pslA and pelA genes play an important role in formation of carbohydrate-rich structure of biofilm matrix (Cotton et al., 2009). pel genes were identified in $P$. aeruginosa (PA14 strain) and its required to produce a glucose-rich matrix material that involved in a thick pellicle formation (Vasseur et al., 2005).

Flagella mediate swimming and swarming motility of $P$. aeruginosa which act as an adhesin and produce cell-to-surface interactions then enable the bacteria to swim and overcome repulsive electrostatic forces that present between the cell surface and the surface of materials forming film (O'Toole and Kolter, 1998). The fliC gene as a key gene involved in flagella production, has an important role in the encoding of subunit protein, flagellin (FliC) (Wolfgang et al., 2004).

Several factors are required for biofilm development, including attachment via adhesive protein, cell aggregation via proteins, extracellular DNA, polysaccharides and cell motility (Kjelleberg and Givskov, 2007). The ability of $P$. aeruginosa to metabolize a variety of nutrients enables them to survive in a variety of habitats by developing biofilms (Meliani and Bensoltane, 2015). Within biofilms microorganisms are generally well protected against influence of antibiotics, disinfectants (Hoiby et al., 2010) and host immune system (Jensen et al., 2010). The ability of $P$. aeruginosa to form biofilm renders its ineffective clearance by immune defense systems and antibiotherapy (Rasamiravaka et al., 2015), that considered as a protective mode that allows bacteria to survive and colonize in hostile environments (Yang et al., 2011).

The aim of this study was to isolate and identify $P$. aeruginosa from diseased broiler chickens and environmental swabs collected from water pipes and tanks. Also examine the susceptibility of this microbe against some common usable antimicrobial agents in addition to detection of some virulence genes using PCR technique and evaluation of its ability to form biofilm in vitro.

\section{MATERIALS AND METHODS}

\section{Samples collection}

One hundred and fifty diseased broiler chickens (Cobb breed) were collected from 40 farms in Dakahlia Governorate at 30 days of age. The collected birds suffered from depression, anorexia with lameness, swollen hock joint, diarrhea and necrotic foci in (liver, spleen and kidney). The mortality rate ranged from $(4 \%)$ to $(10 \%)$ Samples from internal organs such as (liver, heart, lung, spleen, intestine and tracheal swabs were collected aseptically and pooled together for each bird. A total of 50 swabs from water pipes and tanks in chicken farms were also collected aseptically. All samples were labeled and transported directly in ice box to reference laboratory for veterinary Quality Control on poultry production (Dakahlia branch- Gamasa lab.) for further examinations.

\section{2. $P$. aeruginosa isolation and identification}

The collected samples were cultured in nutrient broth tubes and incubated at $37^{\circ} \mathrm{C}$ for 24 hours then loopfull from broth was streaked on nutrient agar, MacConkey and blood agar plates then incubated at $37{ }^{0} \mathrm{C}$ for 24 hours aerobically. The suspected colonies were transferred to nutrient agar slant and stored in refrigerator at $4{ }^{0} \mathrm{C}$ for further identifications (colony morphology, pigment production and biochemical reactions which were preformed following the methods described by MacFadden, (2000).

\section{Antimicrobial susceptibility testing according to Finegold and Martin (1982).}

Antimicrobial susceptibility testing was done by agar disc diffusion method using Muller Hinton agar plates on isolates that confirmed to be $P$. aeruginosa. The used antibiotics were doxycycline $(30 \mu \mathrm{g})$, streptomycin $(10 \mu \mathrm{g})$, amikacin $(30 \mu \mathrm{g})$, gentamycin $(10 \mu \mathrm{g})$, cefotaxime $(30 \mu \mathrm{g})$, ceftazidime $(30 \mu \mathrm{g})$ and colistin sulphate $(10 \mu \mathrm{g})$. The antibiotics were categorized into resistant, intermediate and susceptible categories according to Clinical Laboratory Standards resistance according to (CLSI, 2016).

4. Detection of pslA, pelA and fliC genes in the isolated $P$. aeruginosa

\subsection{DNA extraction}

DNA was extracted from samples using QIAamp

DNA Mini kit (Qiagen, Germany, GmbH) with modifications from the manufacturer's recommendations. Briefly, $200 \mu \mathrm{l}$ of the sample suspension was incubated with $10 \mu \mathrm{l}$ of proteinase $\mathrm{K}$ and $200 \mu \mathrm{l}$ of lysis buffer at $56^{\circ} \mathrm{C}$ for $10 \mathrm{~min}$. After incubation, $200 \mu 1$ of $100 \%$ ethanol was added to the lysate. The sample was then washed and centrifuged following the manufacturer's recommendations. Nucleic acid was eluted with $100 \mu$ l of elution buffer.

4.2. Oligonucleotide primers that used were provided from Metabion (Germany) listed in table (1). 
Table (1): Primers sequences, target genes, amplicon sizes and cycling conditions.

\begin{tabular}{|c|c|c|c|c|c|c|c|c|}
\hline \multirow[t]{2}{*}{ Gene } & \multirow[t]{2}{*}{ Primer sequence } & \multirow[t]{2}{*}{$\begin{array}{l}\text { Seg. } \\
\text { (bp) }\end{array}$} & \multirow[t]{2}{*}{ P. dent. } & \multicolumn{3}{|c|}{$\begin{array}{c}\text { Amplification } \\
35 \text { cycles } \\
\end{array}$} & \multirow[t]{2}{*}{$\begin{array}{c}\text { Final } \\
\text { ext. }\end{array}$} & \multirow[t]{2}{*}{ References } \\
\hline & & & & Sec. dent. & Annealing & Extens. & & \\
\hline \multirow[t]{2}{*}{$p s l \mathbf{A}$} & $\begin{array}{l}\text { F:5'TCCCTACCTC } \\
\text { AGCAGCAAGC-3' }\end{array}$ & 656 & $\begin{array}{l}94^{\circ} \mathrm{C} \\
5 \mathrm{~min} .\end{array}$ & $\begin{array}{c}94^{\circ} \mathrm{C} \\
30 \mathrm{sec} .\end{array}$ & $\begin{array}{c}60^{\circ} \mathrm{C} \\
40 \mathrm{sec} .\end{array}$ & $\begin{array}{c}72^{\circ} \mathrm{C} \\
45 \mathrm{sec} .\end{array}$ & $\begin{array}{c}72^{\circ} \mathrm{C} \\
10 \mathrm{~min} .\end{array}$ & \\
\hline & $\begin{array}{c}\text { R:5'- } \\
\text { TGTTGTAGCCGTA } \\
\text { GCGTTTCTG-3' }\end{array}$ & & & & & & & $\begin{array}{c}\text { Ghadaksaz } \\
\text { et al., } \\
(\mathbf{2 0 1 5})\end{array}$ \\
\hline \multirow[t]{2}{*}{ pelA } & $\begin{array}{c}\mathrm{F}: 5^{\prime}- \\
\text { CATACCTTCAGCC } \\
\text { ATCCGTTCTTC-3' }\end{array}$ & 786 & $\begin{array}{l}94^{\circ} \mathrm{C} \\
5 \mathrm{~min} .\end{array}$ & $\begin{array}{c}94^{\circ} \mathrm{C} \\
30 \mathrm{sec} .\end{array}$ & $\begin{array}{c}60^{\circ} \mathrm{C} \\
40 \mathrm{sec} .\end{array}$ & $\begin{array}{c}72^{\circ} \mathrm{C} \\
45 \mathrm{sec} .\end{array}$ & $\begin{array}{c}72^{\circ} \mathrm{C} \\
10 \mathrm{~min} .\end{array}$ & \\
\hline & $\begin{array}{c}\text { R:5'- } \\
\text { CGCATTCGCCGCA } \\
\text { CTCAG-3' }\end{array}$ & & & & & & & \\
\hline \multirow[t]{2}{*}{ fliC } & $\begin{array}{c}\text { F: } \text { 5'- }^{-} \\
\text {TGAACGTGGCTA } \\
\text { CCAAGAACG -3' }\end{array}$ & 180 & $\begin{array}{l}94^{\circ} \mathrm{C} \\
5 \mathrm{~min} .\end{array}$ & $\begin{array}{c}94^{\circ} \mathrm{C} \\
30 \mathrm{sec} .\end{array}$ & $\begin{array}{l}56.2^{\circ} \mathrm{C} \\
30 \mathrm{sec} .\end{array}$ & $\begin{array}{c}72^{\circ} \mathrm{C} \\
30 \mathrm{sec} .\end{array}$ & $\begin{array}{l}72^{\circ} \mathrm{C} \\
7 \mathrm{~min} .\end{array}$ & \\
\hline & $\begin{array}{c}\text { R:5'- } \\
\text { TCTGCAGTTGCTT } \\
\text { CACTTCGC -3' }\end{array}$ & & & & & & & \\
\hline
\end{tabular}

Seg. $(b p)=$ amplified segment\& P. dent. $=$ primary denaturation $\&$ Sec. dent.$=$ secondary denaturation $\&$ Extens $=$ extension \& Final ext. $=$ final extension

\subsection{PCR amplification}

Primers were utilized in a $25-\mu 1$ reaction containing $12.5 \mu \mathrm{l}$ of EmeraldAmp Max PCR Master Mix (Takara, Japan), $1 \mu \mathrm{l}$ of each primer of $20 \mathrm{pmol}$ concentrations, $4.5 \mu \mathrm{l}$ of water, and $6 \mu \mathrm{l}$ of DNA template. The reaction was performed in an Applied biosystem 2720 thermal cycler.

\subsection{Analysis of PCR products}

The products of PCR were separated by electrophoresis on $1.5 \%$ agarose gel (Applichem, Germany, $\mathrm{GmbH}$ ) in $1 \mathrm{x}$ TBE buffer at room temperature using gradients of $5 \mathrm{~V} / \mathrm{cm}(1.5 \mathrm{gm}$ agarose was prepared in $100 \mathrm{ml} \mathrm{TBE}$ buffer and heated in microwave then allowed to cool at $70^{\circ} \mathrm{C}$, then $0.5 \mu \mathrm{g} / \mathrm{ml}$ ethidium bromide was added and mixed thoroughly. The warm agarose was poured directly in gel casting apparatus with desired comb in apposition and left at room temperature for polymerization). For gel analysis, $20 \mu \mathrm{l}$ of the products was loaded in each gel slot. A gelpilot 100 bp DNA Ladder (Qiagen, Germany, GmbH) and generuler 100 bp ladder (Fermentas, Germany) were used to determine the fragment sizes. The gel was photographed by a gel documentation system (Alpha
Innotech, Biometra) and the data was analyzed through computer software.

\section{Detection of biofilm formation in the isolated $P$. aeruginosa using qualitative tube method}

According to Christensen et al. (1982) and Maram, (2011) with some modifications; a loopful of test organisms was inoculated in $10 \mathrm{~mL}$ of trypticase soy broth with $1 \%$ glucose in test tubes. The tubes were incubated at $37^{\circ} \mathrm{C}$ for 24 hours. One $\mathrm{ml}$ from the inoculated broth was transferred into another tube containing $4 \mathrm{ml}$ trypticase soy broth with $1 \%$ glucose, one tube used as a control negative (not inoculated) and another tube was inoculated with $P$. aeruginosa (positive control). All test tubes were incubated at $37^{\circ} \mathrm{C}$ for 5 days. After incubation, tubes were decanted and washed with phosphate buffer saline ( $\mathrm{pH} 7.3)$ and dried. Tubes were then stained with crystal violet $(0.1 \%)$. Excess stain was washed with deionized water. Tubes were dried in inverted position. The results of tube method were compared with the control positive strain. Biofilm formation was considered positive when a visible film lined the wall and the bottom of the tube. The experiment was performed in triplicate and repeated three times. 


\section{RESULTS}

1- Cultural, morphological, staining characteristics and biochemical reactions of the isolated $P$. aeruginosa

The cultural characteristics of $P$. aeruginosa isolates were large irregular translucent colonies with a greenish diffusible pigment with fruity smell. The isolated micro-organism was Gram negative, motile, rod shape and produce $\beta$ hemolysis on blood agar. Biochemical reactions of the examined $P$. aeruginosa were positive for oxidase, catalase, citrate utilization and urease tests meanwhile negative for indole, methyl red and Voges proskauer tests.
2 - Incidence of $P$. aeruginosa among the examined samples

A total of $20 \mathrm{P}$. aeruginosa isolates were isolated from 200 samples (150 diseased chickens and 50 water pipes and tanks swabs) with an incidence of $(10 \%)$. Sixteen isolates were recorded from internal organs of 150 diseased chickens with an incidence of $(10.66 \%$ ) (16 isolates/150 samples of internal organs); meanwhile 4 isolates were recoded from 50 water pipes and tanks swabs with a percentage of ( 8 $\%)$.

\section{3 - Antimicrobial Susceptibility pattern of the isolated $P$. aeruginosa}

The results of antimicrobial susceptibility testing in table (2) revealed that $P$. aeruginosa isolates were highly sensitive to amikacin, colistin sulphate and gentamycin with percentages of $(90 \%)$, (90\%), $(90 \%),(70 \%)$ and $(65 \%)$ respectively. Doxycycline, ceftazidime and streptomycin showed resistance with a percentages of $(75 \%),(65 \%),(60 \%)$ and $(50 \%)$ respectively.

Table (2): Antimicrobial Susceptibility pattern of the most frequently isolated $P$. aeruginosa isolates.

\begin{tabular}{lccc}
\hline Antimicrobial agent & \multicolumn{2}{c}{ P. aeruginosa (20 isolates) } & Resistant \\
\cline { 2 - 4 } & Sensitive & Intermediate NO. (\%) & NO) \\
\hline NO. $(\%)$ & $18(90 \%)$ & $1(5 \%)$ \\
\hline Cefotaxime & $3(15 \%)$ & $12(60 \%)$ & $5(25 \%)$ \\
\hline Ceftazidime & $2(10 \%)$ & $12(60 \%)$ \\
\hline Colistin sulphate & $18(90 \%)$ & $2(10 \%)$ \\
\hline Doxycycline & $2(10 \%)$ & $3(0 \%)$ & $15(75 \%)$ \\
\hline Gentamycin & $13(65 \%)$ & $4(20 \%)$ & $3(15 \%)$ \\
\hline Streptomycin & $7(35 \%)$ & $3(15 \%)$ & $10(50 \%)$ \\
\hline
\end{tabular}

*Percentage calculated by dividing number of Pseudomonas aeruginosa isolates showed resistance or sensitivity on total number of Pseudomonas aeruginosa isolates

\section{4 - Detection of pslA, pelA and fliC genes in the examined P. aeruginosa isolates}

From figures (1, 2 and 3), pslA, pelA and fliC genes were detected in all of the examined samples with percentage of $(100 \%)$. 


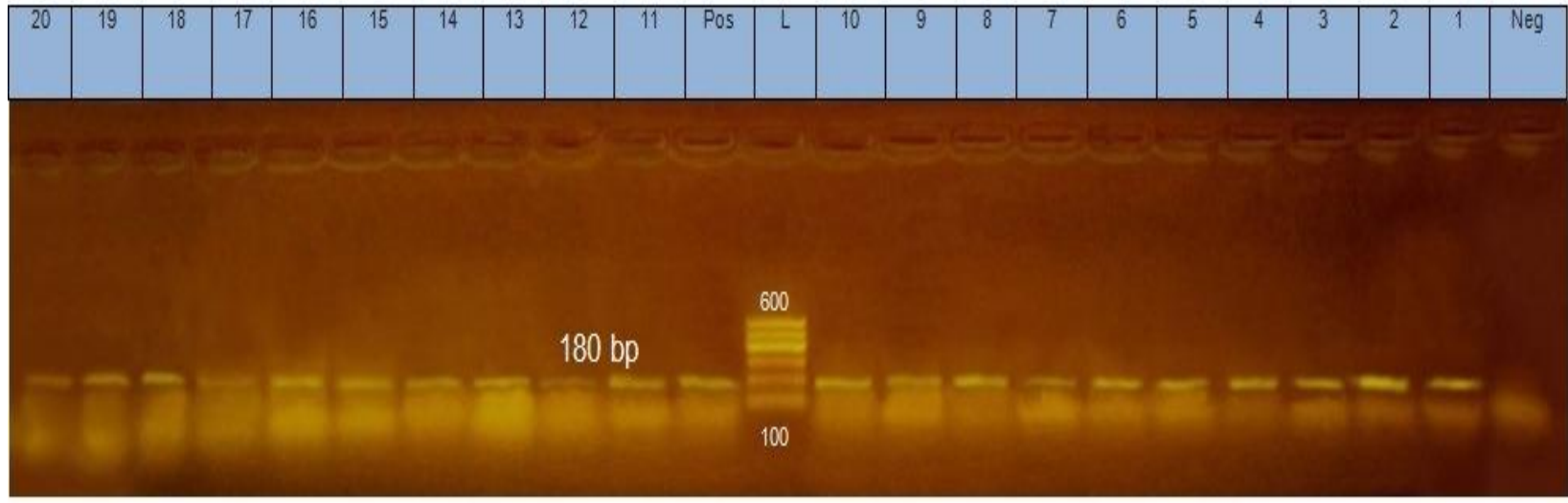

Figure (1): Agarose gel electrophoresis of PCR products for $P$. aeruginosa isolates to detect fliC gene in genomic DNA. Lane L: 100-600 bp DNA ladder. Neg: Negative control, Pos: Positive control. Lane: 1 to 20 were positive samples

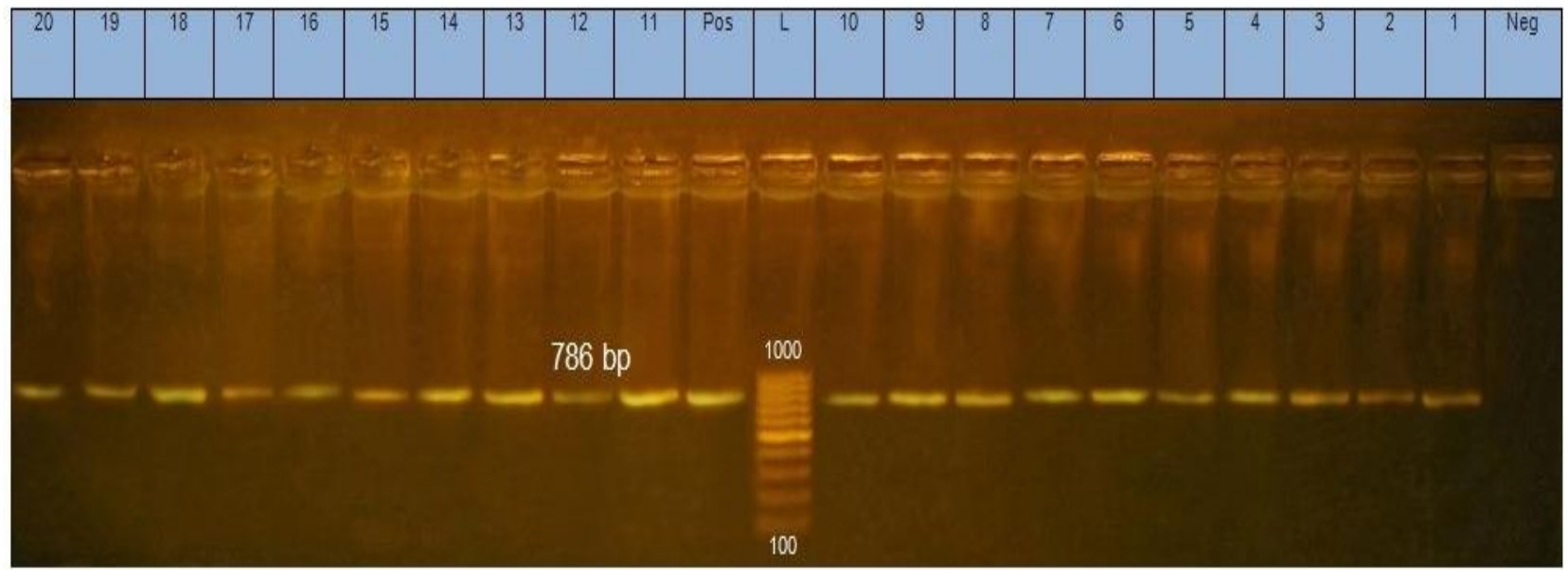

Figure (2): Agarose gel electrophoresis of PCR products for $P$. aeruginosa isolates to detect pelA gene in genomic DNA. Lane L: 100-1000 bp DNA ladder. Neg: Negative control, Pos: Positive control. Lane: 1 to 20 were positive samples

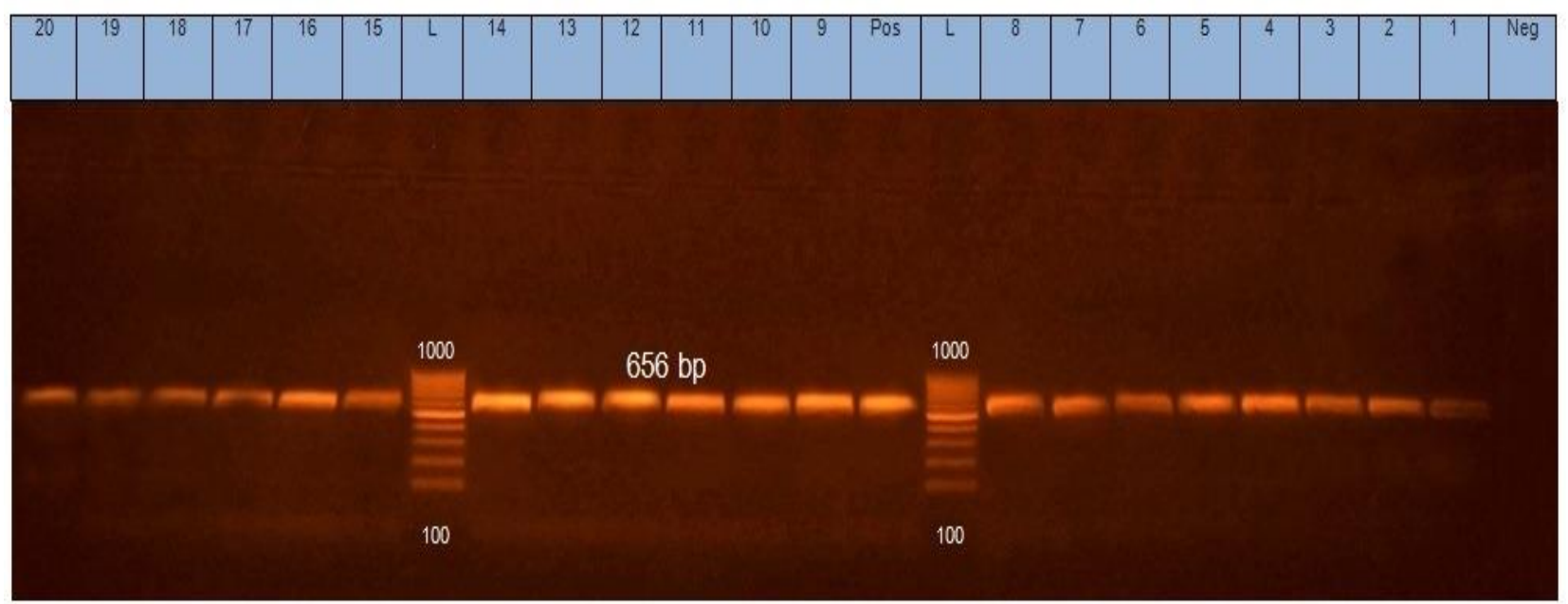

Figure (3): Agarose gel electrophoresis of PCR products for $P$. aeruginosa isolates to detect pslA gene in genomic DNA. Lane L: 100-1000 bp DNA ladder. Neg: Negative control, Pos: Positive control. Lane: 1 to 20 were positive samples

5-Biofilm formation in the examined $\boldsymbol{P}$. positive with a visible film lined the wall and the aeruginosa isolates

A total of $20 \mathrm{P}$. aeruginosa isolates were examined bottom of the test tubes. The experiment was performed in triplicate and repeated three times.

for biofilm formation and all of them were totally 


\section{6-Correlation between biofilm formation, virulence factors and antibiotic resistance in the examined $P$. aeruginos $a$ isolates}

All of the isolated $P$. aeruginosa in this study were found to produce biofilm by using a qualitative tube method. Some virulence factors that have an important role in biofilm formation such as presence of exopolysaccharide and flagella were examined using PCR technique. The percentages of ( $p s l \mathrm{~A}$ and pelA) genes were $(100 \%)$ of the examined strains. The results in this study explain the significant role of such genes in facilitating the attachment of $P$. aeruginosa to inert or living surfaces and enclosed in an extracellular polysaccharide matrixes forming biofilm.

Flagellum plays an extremely important role in production and assembly of biofilm formation. fliC gene that encodes for presence of flagella was detected in this study with a percentage of $(100 \%)$.

In the current study pelA and pslA genes that encodes for these exopolysaccharides were detected and this explains the occurrence of resistance against some of the used antibiotics.

\section{DISCUSSION}

In this study $P$. aeruginosa was isolated from internal organs of diseased chickens with a percentage of $(10.66 \%)$ which was nearly coordinated with Sidhom, (2007) and Omran, (2012) who isolated it from chickens with a percentage of $(13.34 \%)$ and $(12 \%)$ respectively.

Results in this study varied to some extent from Abd El- Tawab et al. (2014) who reported $P$. aeruginosa with a percentage of $(6.25 \%)$ from 224 samples collected from diseased chickens; Younes et al. (1990) who isolated $P$. aeruginosa from 20 dead chickens with percentage of $4.9 \%$. several authors reported a higher incidence of isolation than this study such as Farhan, (2006) who isolated $P$. aeruginosa from infected chickens with an incidence of (20.5\%); Kamel et al. (2011) who isolated P. aeruginosa from poultry respiratory tract with a percentage of $(31 \%)$.

The results of antimicrobial susceptibility testing in table (2) revealed that $P$. aeruginosa isolates were highly sensitive to amikacin, ciprofloxacin, colistin sulphate, norfloxacin and gentamycin with percentages of $(90 \%),(90 \%),(90 \%),(70 \%)$ and $(65 \%)$ respectively. Doxycycline, penicillin, ceftazidime and streptomycin showed resistance with a percentages of $(75 \%),(65 \%),(60 \%)$ and $(50 \%)$ respectively.
A study performed by Abd El-Gawad et al. (1998) reported the same results of the present study; that $P$. aeruginosa isolates from chickens were highly sensitive to colistin sulphate and amikacin. The obtained results agreed with Hassan, (2013) who said that $P$. aeruginosa isolated from chickens showed high sensitivity to amikacin. The results in this study were nearly coordinated with to Abd ElTawab et al. (2014) who reported that P.aeruginosa isolates were sensitive to colistin sulphate and norfloxacin; Kurkure et al. (2001) who stated that $P$. aeruginosa isolated from broiler were sensitive to gentamycin and ciprofloxacin in a percentage $(88.57 \%)$ and $(62.85 \%)$ respectively.

Unlike to our results that reported a higher sensitivity to amikacin and colistin sulphate; a study conducted by El Gohary, (2004) who reported that norfloxacin and ciprofloxacin showed a higher effect of sensitivity on $P$. aeruginosa while amikacin showed a moderate effect.

pslA, pelA and fliC genes were detected in all of the examined samples with percentage of $(100 \%)$. These results varied greatly from that recorded by Ghadaksaz et al. (2015) who reported pslA, pelA and $f l i \mathrm{C}$ genes with percentages of (45.2\%), $(83.7 \%)$ and $(70.2 \%)$ respectively in $P$. aeruginosa isolated from clinical samples.

The results in this study reported that $P$. aeruginosa has the ability to form biofilm and this is also mentioned by several authors such as Price and Ahearn, (1988); Hoiby et al. (2010); Bjarnsholt, (2013); Meliani and Bensoltane, (2015) and Rasamiravaka et al. (2015).

Some virulence factors of $P$. aeruginosa that have an important role in biofilm formation such as presence of exopolysaccharide and flagella were examined using PCR technique. The percentages of ( $p s l \mathrm{~A}$ and pelA) genes were $(100 \%)$ of the examined strains. The results in this study explain the significant role of such genes in facilitating the attachment of $P$. aeruginosa to inert or living surfaces and enclosed in an extracellular polysaccharide matrixes forming biofilm. Some authors such as Cotton et al. (2009) explained the important role of pslA and pelA genes in formation of carbohydrate rich structure of biofilm matrix, any mutations in these genes cause deficiency in the biofilm formation ability.

Flagellum plays an extremely important role in production and assembly of biofilm formation. fliC gene that encodes for presence of flagella was detected in this study with percentage of $(100 \%)$. This fliC gene is one of the key genes in flagella production that have a role in subunit protein encoding, flagellin (fliC) (Feldman et al., 1998), the 
activities of such flagella and type IV pili play a role in biofilm formation (Pratt and Kolter, 1999). In this study there is a significant relationship between the existence of $f l i \mathrm{C}$ gene in the isolated $P$. aeruginosa and the important role that this gene plays in biofilm formation. The same findings were reported by Ghadaksaz et al. (2015) who reported also such significant relationship.

Biofilms are inherently resistant to antibiotics due to their failure to fully diffuse through the biofilm, but some antibiotics are more effective in penetrating and killing cells than others (Stewart, 2001). This explains the variation in antibiotic susceptibility of the used antibiotics in this study, slow diffusion of antibiotics allowing them to be deactivated in the outer layers of the biofilm leading to antibiotic resistance. However, a study performed by Lederberg, (2000) mentioned that antibiotics fail to kill the bacterium in the biofilm even after antibiotic therapy is completed.

The exopolysaccharides (Psl and Pel) form the biofilm matrix of $P$. aeruginosa which protect the bacterial cell from antibiotics and the immune system (Al-Wrafy et al., 2016). In the current study pelA and pslA genes that encodes for these exopolysaccharides were detected and this explains the occurrence of resistance against some of the used antibiotics. Other mechanisms of resistance may also exist including antibiotic modifying enzymes, limited membrane permea-bility for the antibiotics, acqui-sition of chromosomally or plasmid encoded antibiotic resistance genes, mutations (Potron et al., 2015).

In this study the resistance of $P$. aeruginosa to the used aminoglycosides antibiotics is explained by Stewart, (2001) who mentioned that oxygen is often completely consumed by the surface layers of biofilm and creating anaerobic conditions in the less exposed biofilm regions; these anaerobic conditions are often unaffected by aminoglycoside antibiotics. So, the accumulation of waste products produce $\mathrm{pH}$ differences, the acidity prevents the antibiotic from killing all of bacterial in biofilm.

\section{CONCLUSION}

P. aeruginosa is an opportunistic pathogenic bacterium responsible for serious problems in poultry farms. It considered as a good example of environment associated bacteria. Beside its natural resistance to many antimicrobial agents and conventional disinfectants, it has ability to form biofilm. There is increasing evidence that biofilmmediated infection facilitates the development of chronic infectious diseases and recurrent infections due to the inherently resistance of biofilm to antimicrobial agents. Non microbicidal strategies should be applied to struggle biofilm formation such as avoiding microbial attachment to a surface, disrupting biofilm development to enhance the penetration of antimicrobials. Alternative methods of treatment should be applied such as phage therapy. Poultry farms should take all stringent measures of management to overcome any possible sources of pseudomonas infection.

\section{REFERENCES}

Abd El-Tawab, A.A.; El-Hofy, F.I.; Khater, D.F. and Al-Adl, M.M. (2014): PCR detection and gene sequence of Pseudomonas aeruginosa isolated from broiler chickens, Benha Veterinary Medical Journal, 27, 2:449- 455.

Abd El-Gawad, A.M.; Ali, S.M. and Azzaz, H.A. (1998): Some studies on Pseudomonas aeruginosa infection in growing chickens in Assiut farm. Assuit J. Vet. Med., 38 (76): 9097.

Al-Wrafy, F.; Brzozowska, E.; Górska, S. and Gamian, A. (2016): Pathogenic factors of Pseudomonas aeruginosa - the role of biofilm in pathogenicity and as a target for phage therapy. Postepy Hig Med Dosw (online), 70: 78-91.

Barnes, H.J. (2003): Miscellaneous Bacterial Diseases. In: Diseases of Poultry. 11th ed. pp. 852- 854, Iowa State University Press, Ames.

Bjarnsholt, T. (2013): The role of bacterial biofilms in chronic infections, APMIS Supplementum, no. 136 , pp. $1-51$.

Blanc, D.S.; Petigant, C. and Janin, B. (1998): Frequency and molecular diversity of Pseudomonas aeruginosa upon admission and during hospitalization: a prospective epidemiologic study. Clin. Microbiol. Infect., 4: 242- 247.

Christensen, G.D.; Simpson, W.A.; Bisno, A.L. and Beachey, E.H. (1982): Adherence of slime producing strains of Staphylococcus epidermidis to smooth surfaces. Infect Immun; 37:318-326.

Clinical and Laboratory standard institute (CLSI) (2016): M02- A12, M07- A10, and M11- A8.

Cotton, L.; Graham, R.J. and Lee, R.J. (2009): The role of alginate in $P$. aeruginosa PAO1 biofilm structural resistance to gentamicin and ciprofloxacin. J. Exp. Microbiol. Immunol. 13: 58-62.

Devriese, L.A.; Viaene, N.J. and Medts, G. de (1975): Pseudomonas aeruginosa infection on a broiler farm. Journal of Avian Pathology, 4: 233- 237.

Elgohary, A.H.A. (2004): Further investigation of $P$. aeruginosa with reference to products and genetic profile. Ph.D thesis, Dep. of Microbiology (Bacteriology, Mycology and Immunology), Fac. of Vet. Med., Cairo Univ. 
Elsayed, M.S.A.; Ammar, A.M.; Elkerdasy, A.F.; Abd-El Rahman, $H$. and Abd-El Rahman, N.A. (2016): virulence repertoire of Pseudomonas aeruginosa from some poultry farms with detection of resistance to various antimicrobials and plant extracts. Cell Mol Biol 62:124. Doi: 10.4172/1165158x.1000124.

Farhan, H.E. (2006): Bacteriological and histopathological studies on Pseudomonas aeruginosa infection in chickens. M.V.Sc. Thesis (Microbiology), Fac. Vet. Med. Suez canal Univ.

Feldman, M.; Bryan, R.; Rajan, S.; Scheffler, L. and Brunnert, S. (1998): Role of flagella in pathogenesis of Pseudomonas aeruginosa pulmonary infection. Infect Immun 66: 4351.

Finegold, S.M. and Martin, E.T. (1982): Diagnostic Microbiology. $6^{\text {th }}$ ed., the C.V. Mosby Company, St. Louis, Toronto, London.

Ghafoor, A.; Hay, D. and Rehm, B. (2011): Role of Exopolysaccharides in Pseudomonas aeruginosa Biofilm Formation and Architecture. Applied and Environmental Microbiology, 77: 5238-5246.

Ghadaksaz, A.; Imani Fooladi, A.A.; Hosseini, H.M. and Amin, M. (2015): The prevalence of some Pseudomonas virulence genes related to biofilm formation and alginate production among clinical isolates. J. Appl. Biomed., 13 (1): 61-68.

Hai-ping, H.E. (2009): Isolation and identify of Pseudomonas aeruginosa in chicken deadembryos. Chinese Qinghai J Anim Vet Sci, 3: 25-27.

Hancock, R.E. and Speert, D.P. (2000): Antibiotic resistance in Pseudomonas aeruginosa: mechanisms and impact on treatment. Drug Resist Update, 3 (4): 247-255.

Hassan, H.M. (2013): Characterization of Pseudomonas aeruginosa isolated from different pathological lesions in chickens. M. V. Sc. Thesis (Microbiology), Fac. Vet. Med., Beni- Suef Univ.

Hoiby, N.; Ciofu, O. and Bjarnsholt, T. (2010): Pseudomonas aeruginosa biofilms in cystic fibrosis, Future Microbiology, 5 (11): 16631674.

Jensen, P.O.; Givskov, M.; Bjarnsholt, T. and Moser, C. (2010): The immune system vs. Pseudomonas aeruginosa biofilms. FEMS Immunol Med Microbiol 59: 292-305.

Kamel, G.M.; Ezz eldeen, N.A.; El-Mishad, M.Y. and Reham Ezzat, R.F. (2011): Susceptibility Pattern of Pseudomonas aeruginosa Against Antimicrobial Agents and Some Plant Extracts with Focus on its Prevalence in Different Sources. Global Veterinaria, 6 (1): 61-72.
Kjelleberg, S. and Givskov, M. (2007): The Biofilm Mode of Life: Mechanisms and Adaptations (eds. S. Kjelleberg and M. Givskov), Horizon Bioscience, Wymondham, 5-21.

Kurkure, N.V.; Kalorey, D.R.; Shubhangi, W.; Sakhare, P.S. and Bhandarkar, A.G. (2001): Mortality in young broiler due to Pseudomonas aeruginosa. Ind. J. Vet. Res., 10(1): 55-57.

Lederberg, J. (2000): Pseudomonas. Encyclopedia of Microbiology, Second Edition. Volume 3. San Diego, 876-891.

Lin, M.Y.; Cheng, M.C.; Huang, K.J. and Tsai, W.C. (1993): Classification, pathogenicity and drug susceptibility of hemolytic gramnegative bacteria isolated from sick or dead chickens. Avian Dis, 37: 6-9.

MacFadden, J.F. (2000): Biochemical tests for identification of medical bacteria $3^{\text {rd }}$ ED. The Williams \& Wilkins Co., USA: 689- 691.

Maram, M.T. (2011): Studies on Salmonella on Chicken. M.V.Cs thesis, Bacteriology, Immunology and Mycology Department, Faculty of Vet. Med. Mansoura Univ.

Meliani, A. and Bensoltane, A. (2015): Review of Pseudomonas attachment and biofilm formation in food industry, Poult Fish Wild Sci, 3: 126. Doi: 10. 4127/2375446X.100026.

Mena, K.D. and Gerba, C.P. (2009): Risk Assessment of Pseudomonas aeruginosa in water. Rev Environ Contam Toxicol, 201: 71-115.

Omran, G.A. (2012): Characterization of Pseudomonas spp of avian origin. M.V.Sc. Thesis (Microbiology), Fac. Vet. Med. Cairo Univ.

Potron, A.; Poirel, L. and Nordmann, P. (2015): Emerging broad-spectrum resistance in Pseudomonas aeruginosa and Acinetobacter bauman $\neg$ nii: mechanisms and epidemiology. Int. J. Antimicrob. Agents, 45: 568-585.

O'Toole, G.A. and Kolter, R. (1998): Flagellar and twitching motility are necessary for Pseudomonas aeruginosa biofilm development. Mol Microbiol 30: 295-304.

Pratt, L.A. and Kolter, R. (1999): Genetic analyses of bacterial biofilm formation. Curr. Opin. Microbiol. 2:598-603.

Price, D. and Ahearn, D.G. (1988): Incidence and persistence of Pseudomonas aeruginosa in whirlpools. J Clin Microbiol 26: 1650-1654.

Rasamiravaka, T.; Labtani, Q.; Duez, P. and El Jaziri, M. (2015): The Formation of Biofilms by Pseudomonas aeruginosa: A Review of the Natural and Synthetic Compounds Interfering with Control Mechanisms. BioMed Research International, Volume 2015, Article ID 759348, 17 pages. http://dx.doi.org/ 10.1155/2015/759348 
Riad, E.M. (1994): Characterization of pseudomonas species isolated from domestic animals and poultry. Ph. D. Thesis (Microbiology), Fac. Vet. Med. Cairo Univ.

Sidhom, S.S. (2007): Molecular studies on resistant genes of Pseudomonas aeruginosa. M.V.Sc. Thesis (Microbiology), Fac. Vet. Med. Cairo Univ.

Stipkovits, L.; Glavits, R.; Vanics, E. and Szabo, E. (1993): Additional data on Mycoplasma disease of goslings. Avian Pathol., 22:171176.

Stewart, P.S. (2001): The Lancet (North American Edition): Antibiotic Resistance of Bacteria in Biofilms. 358 Vol. Little, Brown and Co.

Vasseur, P.; Vallet-Gely, I.; Soscia, C.; Genin, S. and Filloux, A. (2005): The pel genes of the Pseudomonas aeruginosa PAK strain are involved at early and late stages of biofilm formation. Microbiology, 151, 985-997.
Whitchurch, C.B.; Tolker-Nielsen, T.; Ragas, P.C. and Mattick, J.S. (2002): Extra-cellular DNA required for bacterial biofilm formation. Science, 295: 1487.

Wolfgang, M.C.; Jyot, J.; Goodman, A.L.; Ramphal, R. and Lory, S. (2004): Pseudomonas aeruginosa regulates flagellin expression as part of a global response to airway fluid from cystic fibrosis patients. Proc. Natl. Acad. Sci. U. S. A. 101, 6664-6668.

Yang, L.; Hu, Y.; Liu, Y.; Zhang, J.; Ulstrup, J. and Molin, S. (2011): Distinct roles of extracellular polymeric substances in Pseudomonas aeruginosa biofilm development. Environ. Microbiol., 13: 17051717.

Younes, T.; Youssef, H.; Abd AlKarim, S. and Hassanein, K. (1990): Epidemiologically Studies of $P$. aeruginosa in chickens, fishand human. Assiut, Vet. Med. J., 23(45): 48-56.

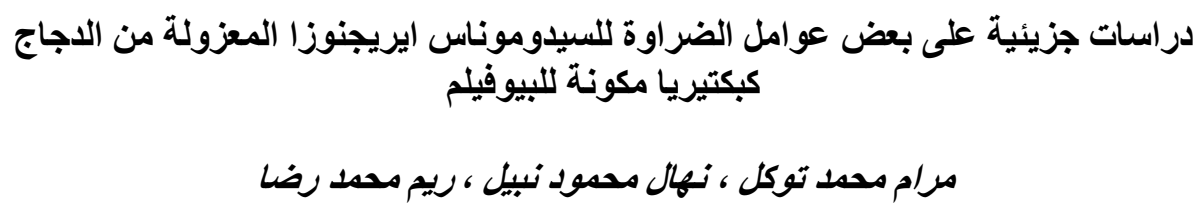

Email: maram_salah82@hotmail.com Assiut University web-site: www.aun.edu.eg

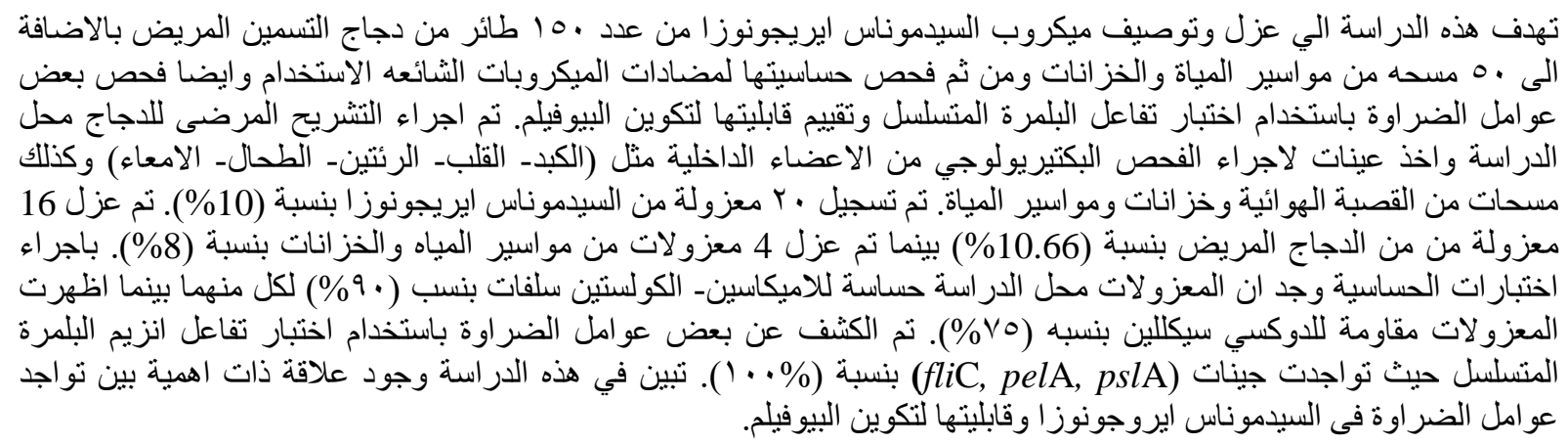

